\title{
Activated chemical defenses in tropical versus temperate seaweeds
}

\author{
Giancarlo L. Cetrulo ${ }^{1, *}$, Mark E. Hay ${ }^{2, * *}$ \\ ${ }^{1}$ University of North Carolina at Chapel Hill, Institute of Marine Sciences, 3431 Arendell St., Morehead City, \\ North Carolina 28557, USA \\ ${ }^{2}$ School of Biology, Georgia Institute of Technology, Atlanta, Georgia 30332-0230, USA
}

\begin{abstract}
Chemical defenses that are rapidly activated in response to injury have been reported in numerous species of vascular plants, but activated chemical defense has been demonstrated for only 1 genus of seaweed. To investigate the frequency of potential activated chemical defenses in seaweeds and to determine if there are geographic differences in the frequency of theses, we conducted urchin and fish feeding assays using chemical extracts from 42 species of temperate or tropical seaweeds that were damaged immediately before extraction in organic solvents (= the potentially activated extract) or placed in organic solvents before they were damaged (= the non-activated extract). Seven species exhibited changes in palatability consistent with activated defenses while 4 species became more, rather than less, palatable if they were damaged $30 \mathrm{~s}$ before extraction. Frequency of activation did not vary geographically. Seventeen percent of tropical species (4 of 24) and $17 \%$ of temperate species (3 of 18) exhibited changes in palatability that were consistent with activation of chemical defenses. Thin-layer chromatography of lipid-soluble extracts indicated that damaging the thallus prior to extraction caused noticeable chemical changes in $70 \%$ of the species evaluated. Investigations of algal chemical defenses thus need to consider the effects of injury during herbivore attacks and the effects of extraction methodology on the types of, and concentrations of, metabolites discovered in seaweeds.
\end{abstract}

KEY WORDS: Activated chemical defenses $\cdot$ Fish $\cdot$ Marine $\cdot$ Plant-herbivore interaction $\cdot$ Sea urchin Seaweed

Resale or republication not permitted without written consent of the publisher

\section{INTRODUCTION}

Herbivory strongly impacts algal distribution, abundance, and community structure in both temperate and tropical communities (e.g., Lubchenco \& Gaines 1981, Carpenter 1986, Lewis 1986, Hay 1997). Sea urchins decimate temperate kelp beds (Lawrence 1975, Steinberg et al. 1995), and either fishes alone or urchins alone can remove 60 to $97 \%$ of total algal production on tropical reefs (Hatcher \& Larkum 1983, Carpenter 1986), reducing competitive pressures on corals and

*Present address: SEA Laboratory, 1021 N. Harbor Dr., Redondo Beach, California 90266, USA

${ }^{* *}$ Corresponding author. E-mail: mark.hay@biology.gatech.edu facilitating the establishment of tropical reefs (Lewis 1986, Hughes 1994, Miller \& Hay 1996).

Macroalgae persist by escaping, tolerating, or deterring herbivores (Lubchenco \& Gaines 1981). One of the more extensively studied methods of deterring herbivores is via the production of chemical defenses (Hay \& Fencial 1988, Paul 1992, Hay 1996). Chemical deterrents are widespread among seaweeds and have important direct and indirect effects on the evolution of seaweed-herbivore interactions and on benthic community structure in general (Hay \& Fencial 1996, Hay 1997).

Plant chemical defenses may be either constitutive (constantly produced) or induced in response to changes in the environment (Karban \& Baldwin 1997). Acti- 
vated chemical defenses are a special case of induced defenses that occur within seconds of damage. Like induced defenses, activated defenses are triggered by injury and result in increased resistance to herbivory. However, activated defenses are similar to constitutive defenses in that the plant has invested resources in the defensive precursors before the injury occurs (Karban \& Baldwin 1997). Activation differs from normal induction in that (1) activated defenses convert a less deterrent metabolite to a more deterrent one, whereas induction involves increased production of an existing metabolite, and (2) activation occurs very rapidly (within seconds) (Paul \& Van Alstyne 1992) whereas induction may take hours to months (Karban \& Baldwin 1997). Although activation is initiated by damage, like an induced defense, it is more similar to constitutive defense because the stored chemical precursors are maintained at high concentrations and the response time to herbivory is very rapid (Paul \& Van Alstyne 1992, Karban \& Baldwin 1997). Activated defenses might be selected over constitutive defenses if the deterrent chemical is physiologically damaging to the plant (Baldwin \& Callahan 1993, Wolfe et al. 1997) or if the defensive chemical attracts specialist herbivores (Carroll \& Hoffman 1980, Giamoustaris \& Mithen 1995).

Activation occurs in numerous terrestrial plants. As examples, several plant families activate hydrogen cyanide in response to injury (Conn 1979), crucifers hydrolyze glucosinolates to form thiocyanates, isothiocyanates, or isonitrils (Van Etten \& Tookey 1979, Chew 1988), and, when damaged, Populus balsamifera rapidly converts phenolic glycosides into more potent feeding deterrents (Clausen et al. 1989, 1991). Activation of chemical defense also appears to occur in one of the few freshwater macrophytes in which specific chemical defenses have been demonstrated (Bolser et al. 1998).

Activation has important methodological as well as ecological implications. Most chemical extractions are done using uninjured plants, but this may not accurately represent the chemistry a herbivore encounters as it macerates a plant while feeding. Comparisons of recently injured versus uninjured plants may show differences in chemistry or palatability that would otherwise go unnoticed, suggesting an enzymatic conversion of precursors to more potent defensive molecules.

Marine examples of activated defenses appear to be rare, but few investigations have looked for them. Tropical green algae in the genus Halimeda convert the less potent halimedatetraacetate into the more deterrent halimedatrial within seconds of being damaged (Paul \& Van Alstyne 1992) and a similar conversion of udoteal to the more deterrent petiodial has been suggested in Udotea flabellum (Paul 1992). The planktonic microalga Emiliania huxleyi converts dimethylsulphoniopropionate (DMSP) to dimethylsulfide (DMS) when cells are lysed, deterring grazing by protozoa herbivores (Wolfe et al. 1997). Our study focused on determining whether rapid changes in the palatability of seaweed extracts following damage was uncommon in marine systems, or simply overlooked.

In this investigation, we determined the frequency of possible activated chemical defenses among seaweeds by testing the deterrence of extracts from undamaged seaweeds versus extracts from plants damaged for $30 \mathrm{~s}$ prior to extraction. Because seaweed chemical defenses appear better developed in tropical than in temperate seaweeds (Bolser \& Hay 1996), we also compared the frequency of activated deterrence for temperate seaweeds from North Carolina versus tropical seaweeds from the Florida Keys.

\section{METHODS}

Study sites and organisms. Tropical algae were collected and field experiments conducted near Key Largo, Florida, USA $\left(24^{\circ} 59^{\prime} \mathrm{N}, 80^{\circ} 24^{\prime} \mathrm{W}\right)$ during August to October 1997. Collection locations were in Florida Bay (Acetabularia calyculus, Caulerpa mexicana, C. prolifera), seagrass beds south and east of Rodriguez Key (Avrainvillea nigricans, Udotea flabellum, Rhipocephalus phoenix, Penicillus dumatosis, Halimeda incrassata, Dictyosphaeria cavernosa, Ceramium nitens, Digenia simplex, Laurencia papillosa, L. intricata, L. poiteaui), in spur and groove zones on Pickles Reef at depths of 6 to $20 \mathrm{~m}$ (Lobophora variegata, Stypopodium zonale, Dictyota dentata, Amphiroa rigida, Halimeda goreaui, H. opuntia, H. tuna), from Pine Key reef (Sargassum pteropleuron), and from surface waters off-shore of Key Largo (Sargassum polyceratium).

Temperate algae were collected near Morehead City, North Carolina, USA, during October 1997 and January to August 1998. Collection locations were at 10 Fathom Rock at a depth of $17 \mathrm{~m}$ (Zonaria turnuefortii, Dictyopteris hoytii, Solieria filiformis, Halymenia trigona, Amphiroa beauvoissi), at Radio Island's rock jetty at a depth of 0.5 to $4.0 \mathrm{~m}$ (Calinitophyllum medium, Chondria sp., Dasya baillouviana, Rhodomenia divaricata, Sargassum filipendula, Scytosiphon lomentaria, Spatoglossum schroederi, Petalonia fascia, Padina gymnospora, Dictyota ciliolate, $D$. menstrualis), from oyster reefs on the mudflat at Mitchell's Village (Ectocarpus sp.), and from intertidal rubble in the Beaufort channel (Fucus vesiculosus).

To determine if chemical defenses were activated by damage, we ground plants in a blender for $30 \mathrm{~s}$ before exposing them to the organic solvents used for extraction (a 2:1 blend of dichloromethane:methanol [= DCM:MeOH] $)$, or we placed intact plants into these solvents prior to blending. This procedure follows that 
used by Paul \& Van Alstyne (1992) in their initial study of activated chemical defenses in the green seaweed Halimeda. Blending for $30 \mathrm{~s}$ chopped most seaweeds into small portions, probably rupturing many individual cells. Given that the pharengil mills of tropical parrotfishes and the aristotle's lantern of sea urchins both crush most of the algal cells consumed, this grinding should be a reasonable mimic of the physical processes occurring as these species feed. The temperate fish we used in our assays does not have these types of mouth parts and tends to bite off sections of plant and swallow these with considerably less cell damage before the seaweed enters the gut. Our grinding procedure may not adequately mimic damage done by herbivores that feed in this manner. The effects of seaweed extracts on herbivore feeding were tested in the field and laboratory using sympatric generalist fishes (tropical parrotfishes, predominantly Sparisoma aurofrenatum and $S$. viride, and the temperate sparid Diplodus holbrooki) and the sea urchin Lytechinus variegata, which occurred in both our temperate and tropical sites. Assays with tropical fishes were conducted in the field where many fishes would have access to our assays, but previous studies at this site (D. Malone pers. comm.) had shown that all feeding on our assay food (the seagrass Thalassia testudinum) was due to parrotfishes and that $94 \%$ of all bites on this food were by the single species $S$. aurofrenatum. Extensive videotaping of transplanted macrophytes and of natural vegetation showed this species to be the most active grazer on these reefs, thus making it an especially appropriate assay organism for the macrophytes. It is the major consumer of common macrophytes such as species of Halimeda, Sargassum and Lobophora (D. Malone \& M. E. Hay pers. obs., based on bite rates from approximately $200 \mathrm{~h}$ of video on these reefs). In temperate fish feeding assays, we used the spottail pinfish Diplodus holbrooki because it is the most common species of plant-eating fish on reefs in the South Atlantic Bight (Hay \& Sutherland 1988) and because its feeding can strongly affect benthic community structure (Hay 1986, Miller \& Hay 1996, Duffy \& Hay 2000).

The sea urchin Lytechinus variegatus is common in both North Carolina and tropical habitats. We collected this sea urchin in North Carolina and used it in feeding choice assays with extracts from both temperate and tropical seaweeds.

Chemical methods. Because previous examples of activated chemical defenses in both seaweeds and freshwater macrophytes were lipid-soluble (Paul \& Van Alstyne 1992, Bolser et al. 1998) and because geographic differences in chemical defenses between seaweeds from the regions we investigated were lipid-soluble rather than water-soluble (Bolser \& Hay 1996), we focused exclusively on the effects of lipid-soluble extracts.
To test whether extracts from injured algae were more, or less, deterrent to herbivores than extracts from intact algae, we extracted injured versus uninjured plants using methods similar to those used by Paul \& Van Alstyne (1992) in their initial study documenting activation of chemical defenses in the genus Halimeda. Algae were collected, spun in a salad spinner to remove excess water, and individual plants divided in half. For species in which plant tissues would be damaged appreciably by this division, individual plants were randomly selected for each treatment. Numerous individual plants were pooled to create each treatment group. The preinjured treatment was submerged in a measured amount of seawater (as determined for each species based on quantity and physical characteristics) and ground for $30 \mathrm{~s}$ in a blender. This damaged algal tissue was then rapidly immersed in 2:1 DCM:MeOH, within about $30 \mathrm{~s}$ after blending. The the non-preinjured treatment (= control) was submerged in the same amount of 2:1 DCM:MeOH, and these solvents were allowed to soak into algal tissue for about $30 \mathrm{~s}$ before blending. Seawater, equal in volume to that added to the preinjured treatment, was then added, and this mixture was blended for $30 \mathrm{~s}$. It appears that enzymes in damaged plants act within seconds to convert less active precursors to more active defensive metabolites, and that this enzymatic conversion is prevented by the presence of organic solvents (Paul \& Van Alstyne 1992, Bolser et al. 1998).

Lipophilic metabolites were extracted from both treatments of each algal species by adding and removing 2:1 DCM:MeOH to and from the blended algae 3 times. The pooled extracts for each treatment were then removed via rotary evaporation, and the lipid-soluble extract was separated from more polar components by partitioning with 1:1 DCM:deionized water. The crude lipid extract was obtained via rotary evaporation of the DCM-soluble material. The remaining algal tissue was dried to a constant mass at $60^{\circ} \mathrm{C}$ and the dry weight of the algal sample was determined through the addition of the extract dry weight to the dry algal mass.

There is a possibility that the types of, or concentrations of, compounds retrieved from particular seaweeds could be affected by the solvents chosen for extraction. However, for initial exploratory research assessing a large number of species and a large range of potential types of metabolites, one needs to choose 1 solvent system and use it across all species investigated. We chose DCM:MeOH because it is the most commonly used solvent mixture for extracting secondary metabolites from fresh seaweeds (e.g., see review of methods by Hay et al. 1998), and because this solvent mixture had been used in the only other investigation of activated seaweed defenses (Paul \& Van Alstyne 1992). 
We evaluated chemical differences between extracts of preinjured and non-preinjured seaweeds by diluting the extracts to equal concentrations in ether and visualizing them using thin-layer chromatography (TLC). Separate TLC plates spotted with each extract type were run in each of 3 solvent mixtures (1:1 ether:hexane, 100\% ether, and 19:1 ether:methanol) to visualize algal metabolites across a range of polarities. After allowing the solvent to migrate up two-thirds of the TLC plate, the plate was removed, the solvent front marked, and the compounds visualized with the aid of UV fluorescence and acid charring. Compounds differing between treatments were noted as a function of $\mathrm{R}_{\mathrm{f}}$ value (distance moved relative to the height of the solvent front), color, method of observation and solvent mixture.

Bioassay methods. We tested for preinjury effects on each algal species by comparing the rate at which herbivores consumed foods treated with the extract from the preinjured treatment versus extract from the nonpreinjured treatment. For assays with tropical fishes, $6 \mathrm{~cm}$ length blades of the palatable seagrass Thalassia testudinum were coated with a solution of the lipophilic extract in diethyl ether so that the extract concentration on the blade following evaporation of the ether approximated the concentration ( $\%$ dry mass) extracted from the algae being tested. Specific procedures for coating the assay food followed methods described in Hay et al. $(1987,1998)$. These procedures had worked well on other tropical reefs in the Caribbean and South Pacific.

Previous work indicated that 88 to $100 \%$ of similar extracts (i.e., non-polar lipids) coated onto the surface of palatable seaweeds could be recovered after 2 to $3 \mathrm{~h}$ in seawater (McConnell et al. 1982) and that $96 \%$ of a specific lipid-soluble metabolite could be recovered after $24 \mathrm{~h}$ in seawater (Hay \& Fenical 1988). A length of $6 \mathrm{~cm}$ was chosen to duplicate the experimental protocol used in previous investigations (Hay 1984, Hay et al. 1987).

Four coated blades from the preinjured or non-preinjured treatments were woven between the strands of a $50 \mathrm{~cm}$ length of 3-strand rope so that $5 \mathrm{~cm}$ of each blade was exposed and available to be consumed. Treatment blades (= extract form preinjured plants) of Thalassia testudinum on one rope were paired with control blades (= extract from non-preinjured plants) on a separate rope by placing the ropes within $\sim 0.5 \mathrm{~m}$ of each other at a depth of about $6 \mathrm{~m}$ on Pickles Reef. Thirty pairs of ropes were used in tests with each algal species against reef fishes. Each replicate pair was separated from the others by $\sim 2 \mathrm{~m}$. All assays were completed within $1 \mathrm{~h}$ of initiation.

When either rope in a replicate pair was observed to have $>50 \%$ of the total Thalassia testudinum blade area removed, the amount removed per blade was determined to the nearest $0.5 \mathrm{~cm}$ of length and the replicate pair was collected. In cases where blades were grazed along the sides instead of from the top down, we cut upper portions of the blades to fill in the grazing scars along the margins and then estimated the length missing.

Temperate fish assays were conducted at the University of North Carolina's Institute of Marine Science, Morehead City, North Carolina, USA. Individual Diplodus holbrooki (spottail pinfish) were housed in each half of a 381 aquarium divided by a partition of plastic mesh. A total of 40 fish were used, with sizes ranging from 10 to $15 \mathrm{~cm}$ standard length. Within an assay, no fish was used more than once (i.e., replicates were independent). However, each fish was used to test multiple species of seaweeds. All fish for these assays were collected from a nearshore wreck and allowed to adjust to the indoor environment for $48 \mathrm{~h}$ prior to being used in assays.

For our preference assays with temperate fish, $6 \mathrm{~cm}$ segments of the palatable alga Gracilaria tikvahiae were coated with extract as in the assay with tropical fishes. Each alga was attached to a weighted clothespin, and 1 activated and 1 control alga were paired and placed in each half of each aquarium so that each alga was equally apparent. When either the treatment or control segment in a replicate was observed to have $>50 \%$ of its length removed, the replicate pair was collected and the amount removed per segment was determined to the nearest $0.5 \mathrm{~cm}$.

Because the sea urchin Lytechinus variegatus occurs in both temperate North Carolina and throughout the tropical Caribbean, we used it in bioassays with extracts from both temperate and tropical seaweeds. Activated extracts or control extracts were coated onto freeze-dried and powdered Ulva spp. at natural concentrations. This was achieved by placing the powdered Ulva spp. in a flask, dissolving the desired amount of extract in ether, and pouring this over the Ulva spp. This mixture was rotary-evaporated to dryness, leaving the extact coated onto the particles of Ulva spp. The powdered Ulva spp. (treated with the extract from preinjured or non-preinjured plants) was incorporated into agar and poured into a mold lying over a piece of window screen (see diagrams in Hay et al. $1994,1998)$. After the agar solidified, the mold was removed, leaving 2 strips (one with activated extract, the other with the control extract) of artificial food adhering to the screen. This method basically makes an artificial seaweed with a graph-paper type matrix (i.e., the squares of the window screen) imbedded inside. The food strips were cut into individual replicates (containing equal amounts of each food type), offered to urchins, and removed when approximately one-half of either choice had been consumed, or at the end of the 
6 h experiment. Consumption was measured by counting the number of window screen squares completely revealed by grazing. Extraction and food preparation were done so the extract from $2 \mathrm{~g}$ algal tissue (dry weight) was incorporated into $2 \mathrm{~g}$ dry mass of Ulva spp.

Statistical analyses. All bioassay results were analyzed by a 2-tailed, paired-sample $t$-test after excluding pairs in which all of both treatments, or neither of either treatment, had been consumed. This is standard procedure for paired-sample tests, justifiable because no consumption or total consumption do not give any data on the relative palatability of the 2 treatments (Glantz 1992). This resulted in a sample size of 15 to 38 replicates per assay.

The majority of species tested showed no significant difference in the effect of the activated versus the control extract. A posteriori power analyses were run in order to determine the likelihood that there was no treatment effect versus the likelihood that the experiment simply had inadequate power to detect such an effect. For these analyses, the minimal detectable effect, $\delta$, was chosen to be $50 \%$ because, on average, there was a $54 \%$ difference in consumption between treatments in the 11 cases that showed significant changes due to activation.

Chi-square analyses were used to determine whether activation was more frequent as a function of geographic region (North Carolina vs Florida) or phylogenetic affinity (red, green, or brown seaweeds). Given the large number of assays we conducted (77) and an $\alpha=0.05$, we would expect about 4 assays to be significant due to chance alone. We used a chi-square test to determine if the number of significant differences we documented was greater than what would be predicted from chance.

\section{RESULTS}

TLC demonstrated that damaging plants for about $30 \mathrm{~s}$ prior to extraction qualitatively altered the chemical composition of $70 \%$ (28 of 40 ) of the species examined by TLC (Appendix 1). However, changes in extract palatability to one or both of the herbivores used in our bioassays were much less frequent than changes in chemical composition, occurring in only $26 \%$ (11 of 42 ) of the species examined, with 7 species $(16.7 \%)$ becoming significantly less palatable and 4 species $(9.5 \%)$ becoming significantly more palatable (Figs. 1 to 5). For the 7 species in which damage created more deterrent extracts (i.e., those suggesting an activated chemical defense, Figs. 1, 2 \& 4), TLC of the extracts showed unique compounds in the control extracts of 3 species (Dictyota sp., Halimeda incrassata, and Zonaria tournefortii) and unique compounds in the acti- vated extracts of 4 species (H. tuna, Rhipocephalus phoenix, D. menstrualis, and Scytosiphon lomentaria) (Appendix 1). For the 4 species in which damage resulted in extracts that were more, rather than less, palatable (Figs. 2 to 4), 2 showed unique compounds in the activated extract (Laurencia poiteaui and Petalonia fascia), 1 showed a unique compound in the control extract (Acetabularia calyculus), and 1 showed no detectable difference between extracts (D. ciliolata). Given this variance in how damage changed chemistry versus palatability of the lipid-soluble extracts, tracking the chemistry involved in altered palatability will clearly require bioassay-guided fractionation and isolation of the specific chemicals, or concentrations of chemicals, altering palatability. The TLC results (Appendix 1) coupled with the bioassay results (Figs. 1 to 5) suggest that some of the important chemical changes will be quantitative (not well evaluated by TLC) rather than simply qualitative.

Although we evaluated more tropical species than temperate species, the proportion demonstrating activation was equivalent between these geographic regions. Four of 24 tropical species (17\%; Figs. 1 to 3 ) and 3 of 18 temperate species (17\%; Figs. 4 \& 5) had activated extracts that were significantly less palatable than control extracts to at least one of our herbivores. In addition to the significant alterations in palatability that are discussed above, 3 tropical species (Sargassum polyceratium, Halimeda opuntia, and Digenia simplex) showed non-significant trends (e.g., p $=0.069$ to 0.083 ) suggestive of activation (Figs. 1 to 3 ).

The proportion of species whose extracts differed in palatability (becoming either more deterrent or more attractive) as a result of damage did not differ between temperate and tropical regions (tropical $=4$ deterrent, 2 attractive, and 18 showing no change; temperate $=3$ deterrent, 2 attractive, and 13 showing no change [chisquare $p$-value $=0.156]$ ). If we made this contrast only within the brown algae or only with the red algae (the lack of temperate green algae in our assays prevented such an analysis for this group), we also found no significant difference with latitude (chi-square $\mathrm{p}$-value $=$ 0.231 and 0.182 , respectively).

The 2 herbivores used in our bioassays of algal extracts did not always show similar patterns in feeding. The preinjured extracts from Dictyota sp. (Fig. 1) and D. menstrualis (Fig. 4) were consistently deterrent to both the fish and the urchin, and the preinjured extract from Petalonia fascia (Fig. 4) was more palatable to both herbivores. However, preinjured versus non-preinjured extracts from Acetabularia calyculus, Halimeda incrassata, H. tuna, Rhipocephalus phoenix (Fig. 2), Laurencia poiteaui (Fig. 3), D. ciliolata, Scytosiphon lomentaria, and Zonaria tournefortii (Fig. 4) all differed significantly for one herbivore, but not for the other. 

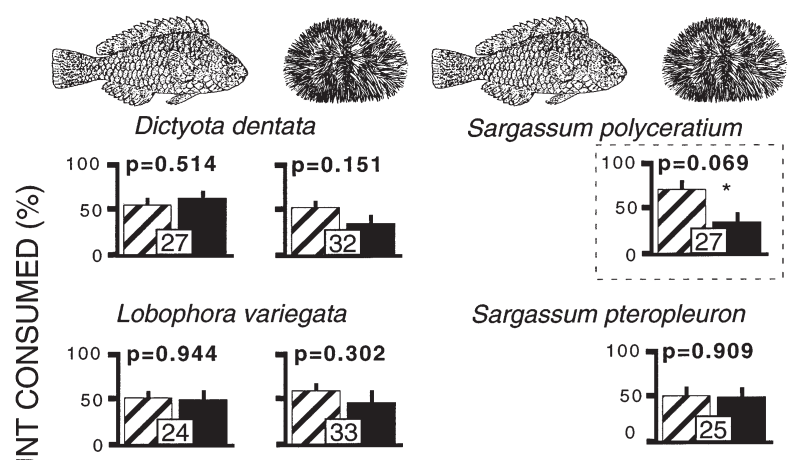

Sargassum pteropleuron

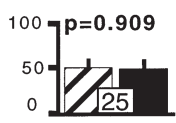

Dictyota sp.

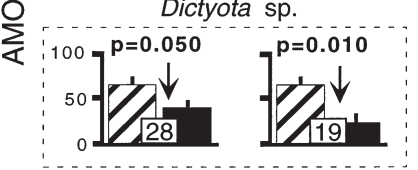

Stypopodium zonale

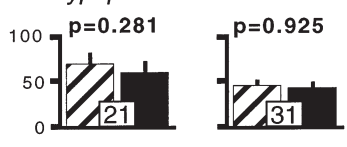

Fig. 1. Assays with extracts from tropical brown algae. Hatched bars show feeding on food treated with extracts from seaweeds that were not damaged before exposure to organic solvents ( $=$ controls); solid bars indicate feeding on food treated with extracts from preinjured seaweeds (= activated extracts). Graphs below fish indicate parrotfish assays. Graphs below urchins indicate urchin assays. Sample size is given at the base of each histogram pair. Error bars indicate $1 \mathrm{SE}$. p-values are from a 2-tailed, paired-sample $t$-test. Dashed lines around a graph highlight significant ( $\mathrm{p} \leq 0.05$ ), or nearly significant $(0.05<\mathrm{p}<0.10)$ differences. Down-pointing arrows indicate an activated defense; ${ }^{*}$ Nearly significant trends

The degree of confidence that one may have in several of the above contrasts will depend upon the power of our assays to detect an altered palatability of the extract. Of the 78 feeding assays performed, a significant difference in the palatability of preinjured versus non-preinjured extracts was detected in 14. These contrasts are irrelevant to a posteriori power analysis (Peterman 1990). Of particular interest for questions involving power are those assays with large differences between treatment means and $p$-values that are near 0.05 . For the 7 instances that met these criteria (e.g., p < 0.20), power analyses indicated that we had a $\geq 75 \%$ chance of detecting a $50 \%$ change in feeding, indicating that the power to detect a significant difference between treatments was reasonable. The remaining 56 assays had smaller differences between treatments and larger p-values ( $p>0.20)$. For 10 of these assays, power to detect a $50 \%$ change in feeding was $<75 \%$ (ranging from 74.2 to $57.5 \%$ ). All assays with low power involved urchins; power was relatively high in all fish assays.

With 77 separate assays and an $\alpha$-value set at 0.05 , chance alone would be predicted to produce 4 significant differences (i.e., $0.05 \times 77=3.85$ ). The 13 significant differences that we observed significantly exceed the frequency of differences that would be expected by chance ( $p=0.021$, chi-square test).

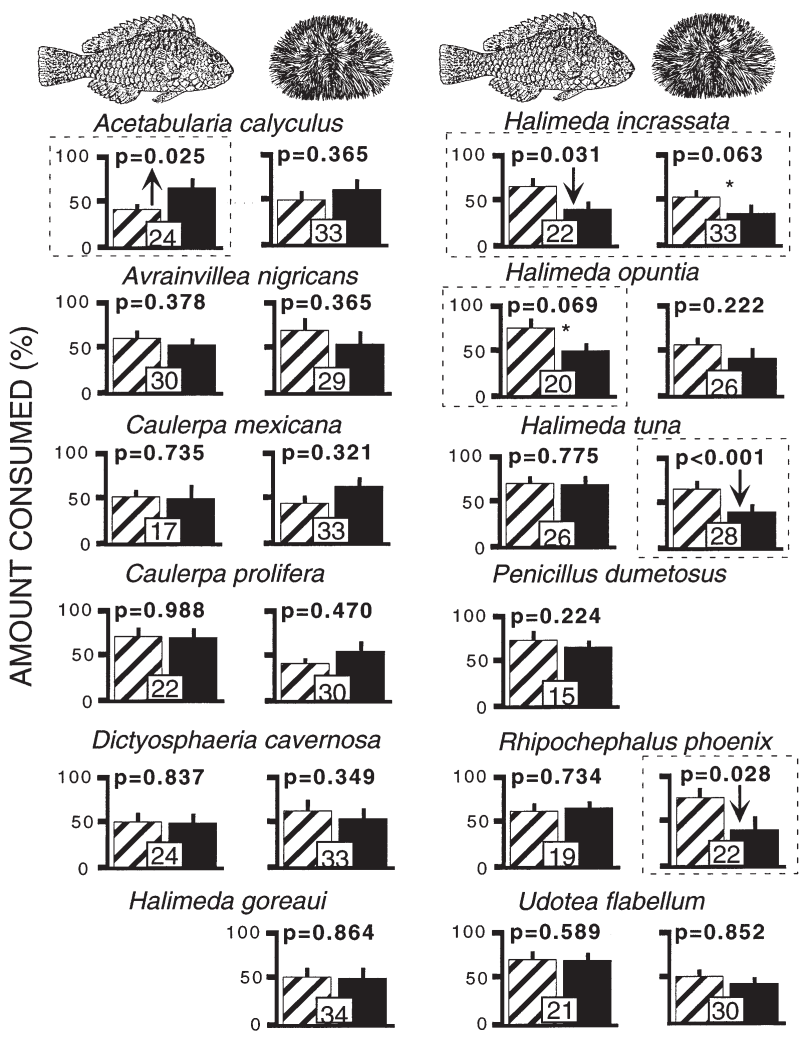

Fig. 2. Assays with extracts from tropical green algae. Uppointing arrows indicate species in which damage increased, rather than decreased, palatability. Symbols and analyses as in Fig. 1

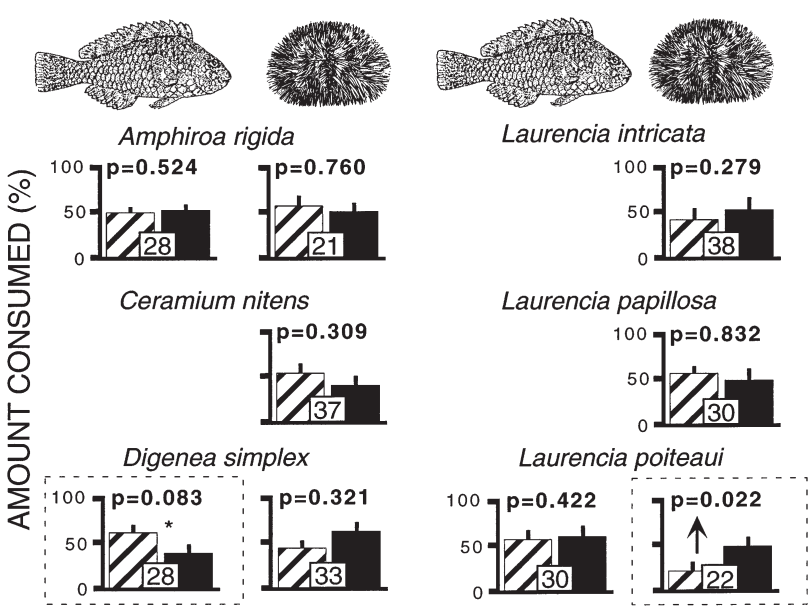

Fig. 3. Assays with extracts from tropical red algae. Symbols and analyses as in Figs. 1 \& 2

\section{DISCUSSION}

Although $70 \%$ of the species examined using TLC showed qualitative differences in chemistry between the extracts from preinjured and non-preinjured plants, extracts from preinjured plants were more deterrent 


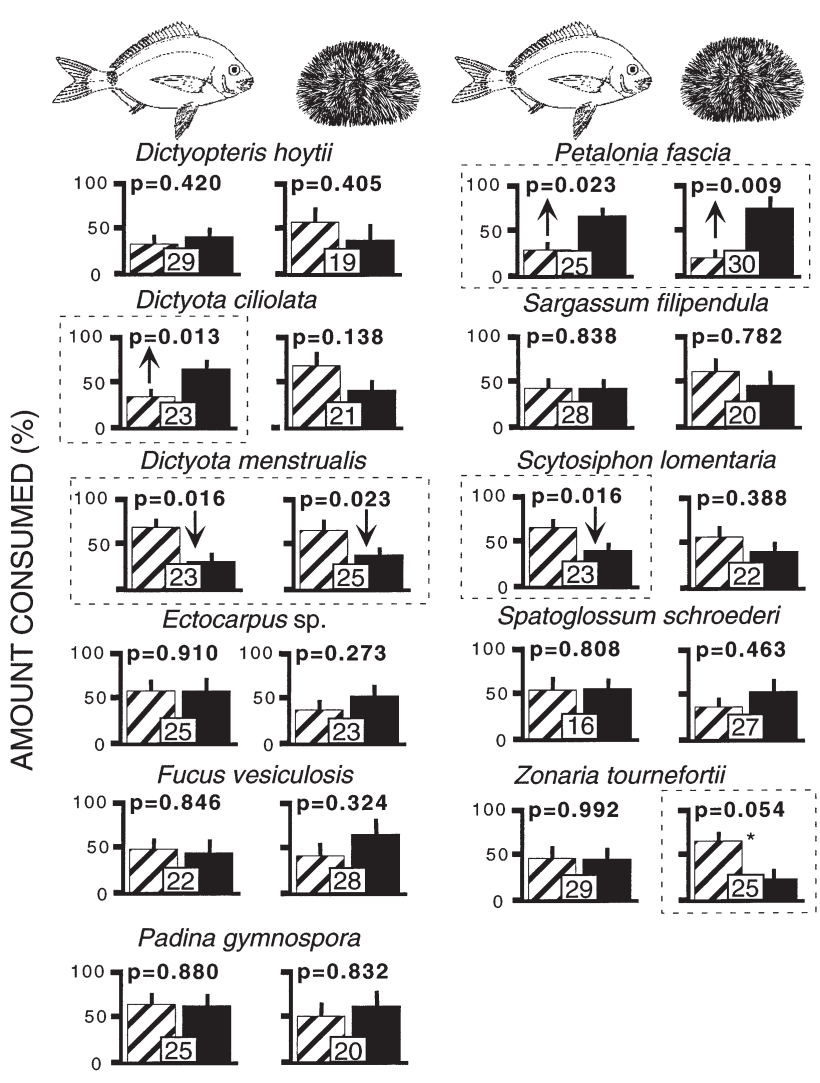

Fig. 4. Assays with extracts from temperate brown algae. Graphs below fish indicate assays with spot-tail pinfish. Graphs below urchins indicate urchin assays. Symbols and analyses as in Figs. 1 \& 2

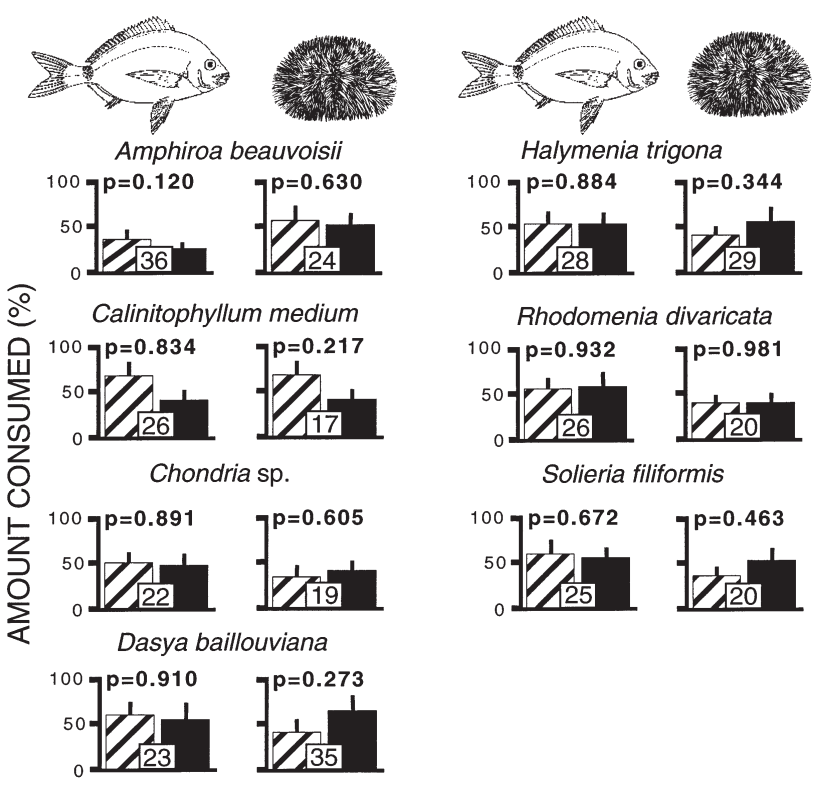

Fig. 5. Assays with extracts from temperate red algae. Symbols and analyses as in Figs. 1 \& 2 to at least one herbivore for only $17 \%$ of the species tested. In contrast to expectations based on the activation of chemical defenses, extracts from preinjured plants were significantly more palatable than extracts from non-preinjured plants for about $10 \%$ of the species investigated. Thus, extract palatability immediately changed in response to damage in about $26 \%$ of the species tested, with 7 of 42 species showing decreased palatability and 4 of 42 species exhibiting increased palatability as a result of damage.

Despite the evidence that intense herbivory has selected for increased chemical defenses among tropical compared to temperate plants in both terrestrial and marine systems (Coley \& Aide 1990, Bolser \& Hay 1996), our study found no evidence that the frequency of activated chemical defenses varied between the 2 geographic localities we investigated. However, tropical areas are not uniform in their intensity of herbivory, but instead contain a mosaic of spatial and temporal refuges (Hay 1984, 1985, 1997). Over half of the tropical species we tested were collected from seagrass habitats and from non-reef habitats in Florida Bay. Macrophytes in these types of habitats experience less selection for antiherbivore defenses (Hay 1984, 1991, Lewis 1985). Despite this, 2 of the 4 tropical species showing evidence for activated defenses (Halimeda incrassata and Rhipocephalus phoenix) were collected in seagrass habitats. These species, however, also occur in reef-slope habitats where herbivory can be intense.

Our results suggest that activation of deterrence may be most common among Dictyotalean brown algae and calcified green algae in the Halimedaceae. Alterations in palatability that would suggest activated chemical defenses did not occur in any of the red seaweeds we investigated, despite many red algae being rich in bioactive secondary metabolites (Hay \& Fenical 1988, Faulkner 1998), several of which have been shown to deter feeding by reef herbivores (Hay et al. 1987, 1988a, Hay 1991, Paul 1992). The only effect of damage that we found for red seaweeds was that the extract from the preinjured treatment of Laurencia poiteaui was preferred over the non-preinjured treatment in urchin preference assays (Fig. 3).

The results of this study combined with Paul \& Van Alstyne's (1992) initial investigation of activated chemical defenses indicate that of the 7 species showing activated defenses, 3 are calcified greens in the family Halimedaceae and 3 are brown algae in the family Dictyotaceae. However, activated chemical defenses are not universal in these families, or even within genera where the types of defensive metabolites produced are relatively similar. Numerous Dictyotalean algae failed to show activation following damage (e.g., Dictyota dentata, D. hoytii, Lobophora variegata, Stypopodium zonale, Padina gymnospora, Spatoglossum schroderi), 
and the extract of 1 species ( $D$. ciliolata) became more palatable following damage. Similarly, Rhipocephalus phoenix and many Halimeda spp. showed significant changes in palatability, or strong trends, indicating an activated defense (Fig. 2), but $H$. goreaui, Udotea flabellum, Avrainvillea nigricans, and Penicillus dumetosus all failed to show evidence for activation, despite being in the family Halimedaceae. It is interesting that all cases of altered palatabilities that are consistent with changes due to activated chemical defenses occurred among species that are known to be chemically defended from some common herbivores (see reviews by Hay 1991, Paul 1992). This suggests that most of these cases of increased deterrence may have been due to activation of chemical defenses rather than due to degradation of feeding stimulants, which could also be caused by damage. The specific chemical changes occurring in activated extracts were not investigated in our study, but bioassay-guided chemical investigations would be a logical next step toward understanding the chemical mechanisms producing the changes in palatability we documented. This mechanistic understanding would allow an evaluation of which alterations in palatabilities were due to changes in chemical defenses and which were due to changes in feeding stimulants, rather than defenses. Damage-induced changes in chemical defenses have been studied in the green seaweed Halimeda. Species in the family Halimedaceae produce several structurally similar diterpenoid metabolites. Most Halimeda spp. produce halimedatetraacetate and the epimers halimedatrial and epihalimedatrial (Paul \& Fenical 1986). Levels of halimedatetraacetate and halimedatrial differ among plants and plant parts depending upon tissue age and intensity of herbivory in the habitat (Hay et al. 1988b, Paul \& Van Alstyne 1988), and Paul \& Van Alstyne (1992) demonstrated that some species of Halimeda produce increased levels of halimedatrial within seconds of being damaged. Other green algae, including species in the genera Penicillus, Udotea, Rhipocephalus, and Caulerpa, have been shown to produce higher concentrations or different types of secondary compounds in areas with intense herbivory versus areas with low levels of herbivory (Paul \& Fenical 1986). However, the ability to activate chemical defenses as a function of herbivore feeding at particular sites has not been evaluated.

Like terpenoid defenses produced by species of Halimeda, diterpenoid defenses of brown algae in the genus Dictyota have been investigated extensively (e.g., Hay et al. 1987, Duffy \& Hay 1994, Cronin \& Hay 1996a,b, Stachowicz \& Hay 1999). However, activation of defenses (Figs. $1 \& 4$ ), or of susceptibility (Fig. 4), was unknown for this genus, or for any brown seaweed, prior to this investigation. We tested 2 tropical and 2 temperate species of Dictyota and found evi- dence consistent with activated defenses against both fish and urchins in the tropical Dictyota sp. (Fig. 1) and the temperate $D$. menstrualis (Fig. 4). In contrast, $D$. dentata from Florida showed no effect of activation (Fig. 1), and D. ciliolata from North Carolina became more susceptible to fish grazing following our activation treatment (Fig. 4); susceptibility to urchins tended to decline, but this change was not significant ( $p=$ 0.138 ). Given the very similar diterpene alcohols that defend $D$. ciliolata and $D$. menstrualis against local herbivores (Cronin \& Hay 1996a,b,c), it would be especially instructive to determine the mechanistic level chemical changes that produce the very different changes in palatability that occur in response to damage of these seaweeds.

While the chemistry of secondary metabolites is described for many algae, it is unclear how some seaweeds sequester bioactive precursor compounds away from activating enzymes. Examples of activation in terrestrial plants suggest that some plants may compartmentalize precursor compounds into vacuoles and physically separate them from activating enzymes (Conn 1979). Certain red algae store terpenoids in vesicles (Young et al. 1980) and brown algae localize phlorotannins in subcellular bodies termed physodes (Ragan \& Glombitza 1986). Siphonous green algae contain protein bodies that migrate to sites of injury, plug these wounds, and prevent further loss of protoplasm (Bold \& Wynne 1978). It is possible that these bodies could also contain defensive precursors or enzymes to activate these precursors, but this has not been investigated.

Two tropical and 3 temperate species' bioassay results indicate that injury may result in increased palatability, an outcome contrary to the notion of activated defenses. Although the cause of this difference is not known, several possibilities exist. Injury could release deterrent compounds that react or degrade vary rapidly, and immersing the species in solvent prior to injury may have preserved such compounds. Alternatively, the activation treatment could have released stimulatory compounds that were not released in the control treatment, or damage we inflicted prior to extraction could have caused degradation of feeding stimulants.

Rapid qualitative changes in algal chemistry in response to injury appear to be common in marine algae. We detected such changes in $70 \%$ of the 40 species we evaluated by TLC. However, activated changes in chemical defenses against herbivores appear to be less common. Damage before extraction produced more deterrent lipid extracts for only $17 \%$ of the 42 species we evaluated. In contrast to expectations based on activated chemical defenses, we found that about $10 \%$ of the species we investigated produced more 
palatable extracts if they were damaged prior to extraction.

These significant changes in extract palatability caused by damage that occurred for about $30 \mathrm{~s}$ prior to extraction raise several questions regarding studies of prey chemical defenses. Our findings suggest that (1) modest variations in how prey are treated immediately prior to extraction (e.g., are they placed in solvent and then ground, or first cut into small pieces that will fit into the small vials sometimes used for initial extractions) could introduce considerable methodological variance into studies of prey chemical defenses, and (2) for studies of chemical defense against herbivores like urchins and fishes that crush plants as they feed, it may be more ecologically realistic to crush plants for short periods before extraction than it is to carefully protect them from stress until they are placed into solvents.

Additionally, we did not evaluate the effects of particular solvents in producing any of the patterns we documented. However, it is possible that some of the patterns in extract palatability (Figs. 1 to 5) or chem- istry (Appendix 1) could be solvent-specific, and it is clear that neither fishes nor sea urchins will be using organic solvents such as DCM/MeOH to extract plants. As a final caution, we also did not evaluate changes in chemistry or extract palatability as a function of damage done for shorter or longer periods before extraction in solvents. Timing of damage, extent of damage, gut traits of the herbivores, or any number of other conditions could impact the effects that plant chemical defenses will have on herbivores. Our present understanding of the variance produced by such considerations is too poorly developed to suggest that particular procedures should be employed under all circumstances. However, as investigations of aquatic chemical ecology continue to mature, these types of questions will need additional attention.

Acknowledgements. Primary funding was provided by NSF grant OCE 95-29784 to M.E.H. Additional support came from the University of North Carolina at Wilmington's National Undersea Research Center and from the Harry and Linda Teasley Endowment to the Georgia Institute of Technology.

Appendix 1. $\mathrm{R}_{\mathrm{f}}$ values for spots present in only 1 treatment

\begin{tabular}{|c|c|c|c|c|}
\hline & Activated & Control & Traits & Solvent regime \\
\hline \multicolumn{5}{|l|}{ Tropical species } \\
\hline Acetabularia calyculus & & 0.73 & UV activity & 19:1 ether:methanol \\
\hline Amphiroa rigida & 0.37 & & UV activity & 1:1 ether:hexane \\
\hline Amphiroa rigida & 0.68 & & UV activity & 1:1 ether:hexane \\
\hline Avrainvillea nigricans & & 0.63 & Chars pink & 1:1 ether:hexane \\
\hline Avrainvillea nigricans & & 0.65 & Chars pink & 1:1 ether:hexane \\
\hline Caulerpa mexicana & & 0.64 & UV activity & 1:1 ether:hexane \\
\hline Caulerpa mexicana & & 0.6 & UV activity & 1:1 ether:hexane \\
\hline Caulerpa mexicana & & 0.36 & UV activity & 1:1 ether:hexane \\
\hline Caulerpa prolifera & 0.40 & 0.27 & Chars pink & 1:1 ether:hexane \\
\hline Ceramium nitens & & 0.22 & Brown & 1:1 ether:hexane \\
\hline Dictyosphaeria cavernosa & & 0.70 & UV activity & 1:1 ether:hexane \\
\hline Dictyota dentata & No difference & & & \\
\hline Dictyota sp. & & 0.05 & Orange & $100 \%$ ether \\
\hline Digenia simplex & No difference & & & \\
\hline Halimeda goreaui & No TLC & & & \\
\hline Halimeda incrassata & & 0.71 & Chars red & 1:1 ether:hexane \\
\hline Halimeda incrassata & & 0.77 & Yellow & 1:1 ether:hexane \\
\hline Halimeda incrassata & & 0.55 & UV activity & 1:1 ether:hexane \\
\hline Halimeda opuntia & 0.58 & & Pink & 1:1 ether:hexane \\
\hline Halimeda opuntia & 0.32 & & Grey & 1:1 ether:hexane \\
\hline Halimeda opuntia & 0.18 & & Grey & 1:1 ether:hexane \\
\hline Halimeda opuntia & 0.05 & & Yellow & 1:1 ether:hexane \\
\hline Halimeda opuntia & & 0.6 & UV activity & $100 \%$ ether \\
\hline Halimeda tuna & 0.52 & & UV activity & $100 \%$ ether \\
\hline Halimeda tuna & 0.44 & & UV activity & $100 \%$ ether \\
\hline Laurencia intricata & No TLC & & & \\
\hline Laurencia poiteaui & 0.35 & & UV activity & 1:1 ether:hexane \\
\hline Laurencia poiteaui & 0.39 & & UV activity & 1:1 ether:hexane \\
\hline Laurencia papillosa & & 0.16 & UV activity & 1:1 ether:hexane \\
\hline Lobophora variegata & 0.56 & & Chars pink & $100 \%$ ether \\
\hline Lobophora variegata & 0.63 & & UV activity & $100 \%$ ether \\
\hline Penicillus dumatosis & 0.71 & & Yellow & 1:1 ether:hexane \\
\hline Rhipocephalus phoenix & 0.71 & & Chars yellow & 1:1 ether:hexane \\
\hline Sargassum polyceratium & & 0.4 & UV activity & 1:1 ether:hexane \\
\hline Sargassum pteropleuron & & 0.4 & UV activity & 1:1 ether:hexane \\
\hline Stypopodium zonale & 0.47 & & UV activity & 1:1 ether:hexane \\
\hline Udotea flabellum & 0.56 & & UV activity & 1:1 ether:hexane \\
\hline Udotea flabellum & 0.19 & & UV activity & 1:1 ether:hexane \\
\hline
\end{tabular}


Appendix 1 (continued)

\begin{tabular}{|c|c|c|c|c|}
\hline & Activated & Control & Traits & Solvent regime \\
\hline \multicolumn{5}{|l|}{ Temperate species } \\
\hline Amphiroa beauvoissi & 0.32 & & Chars brown & 1:1 ether:hexane \\
\hline Calinitophyllum medium & No difference & & & \\
\hline Chondria sp. & No difference & & & \\
\hline Dasya baillouviana & No difference & & & \\
\hline Dictyopteris hoytii & No difference & & & \\
\hline Dictyota ciliolata & No difference & & & \\
\hline Dictyota menstrualis & 0.6 & & Chars pink & $100 \%$ ether \\
\hline Dictyota menstrualis & 0.72 & & Chars blue & $100 \%$ ether \\
\hline Ectocarpus sp. & 0.72 & & Yellow & 1:1 ether:hexane \\
\hline Ectocarpus sp. & 0.31 & & Green & 1:1 ether:hexane \\
\hline Ectocarpus sp. & 0.22 & & Green & 1:1 ether:hexane \\
\hline Ectocarpus sp. & 0.04 & & Chars orange & 1:1 ether:hexane \\
\hline Fucus vesiculosis & No difference & & & \\
\hline Halymenia trigona & No difference & & & \\
\hline Padina gymnospora & No difference & & & \\
\hline Petalonia fascia & 0.28 & & Green & 1:1 ether:hexane \\
\hline Rhodomenia divaricata & No difference & & & \\
\hline Sargassum filipendula & & 0.23 & Green & 1:1 ether:hexane \\
\hline Scytosiphon lomentaria & 0.45 & & UV activity & $100 \%$ ether \\
\hline Solieria filiformis & & 0.26 & Chars orange & 1:1 ether:hexane \\
\hline Spatoglossum schroederi & No difference & & & \\
\hline Zonaria tournefortii & & 0.60 & UV activity & $100 \%$ ether \\
\hline
\end{tabular}

\section{LITERATURE CITED}

Baldwin IT, Callahan P (1993) Autotoxicity and chemical defense: nicotine accumulation and carbon gain in solanaceous plants. Oecologia 94:534-541

Bold HC, Wynne MJ (1978) Introduction to the algae: structure and reproduction. Prentice Hall, Inc, Englewood Cliffs, NJ

Bolser RC, Hay ME (1996) Are tropical plants better defended? Palatability and chemical defenses of temperate vs. tropical seaweeds. Ecology 77:2269-2286

Bolser RC, Hay ME, Lindquist N, Fenical W, Wilson D (1998) Chemical defenses of freshwater macrophytes against crayfish herbivory. J Chem Ecol 24:1639-1658

Carpenter RC (1986) Partitioning herbivory and its effects on coral reef algal communities. Ecol Monogr 56:345-365

Carroll CR, Hoffman CA (1980) Chemical feeding deterrent mobilized in response to insect herbivory and counteradaptation by Epilachna tredecimnotata. Science 209:414-416

Chew FS (1988) Biological effects of glucosinolates. In: Cutler GG (ed) Biologically active natural products: potential use in agriculture. Am Chem Soc Symp Ser 380:155-181

Clausen TP, Reichardt PB, Bryant JP, Werner RA, Post K, Frisby $\mathrm{K}$ (1989) Chemical model for short-term induction in quaking aspen (Populus tremuloides) foliage against herbivores. J Chem Ecol 15:2335-2346

Clausen TP, Reichardt PB, Bryant JP, Werner RA, Post K, Frisby K (1991) Long-term and short-term induction in quaking aspen: related phenomena? In: Tallamy DW, Raupp MJ (eds) Phytochemical induction by herbivores. Johy Wiley, New York, p 71-83

Coley PD, Aide TM (1970) Comparison of herbivory and plant defenses in temperate and tropical broad-leaved forests. In: Price PN, Lewinson TM, Fernandez GW, Benson WW (eds) Plant-animal interactions: evolutionary ecology in tropical and temperate regions. Wiley, New York, p 25-49

Conn EE (1979) Cyanide and cyanogenic glycosides. In: Rosenthal GA, Janzen DH (eds) Herbivores: their interaction with secondary plant metabolites. Academic Press, New York, p 387-412
Cronin G, Hay ME (1996a) Amphipod grazing and induction of seaweed chemical defenses. Ecology 77:2287-2301

Cronin G, Hay ME (1996b) Susceptibility to herbivores depends on recent history of both the plant and animal. Ecology 77 : $1531-1543$

Cronin G, Hay ME (1996c) Within-plant variation in seaweed palatability and chemical defenses: optimal defense theory versus the growth-differentiation balance hypothesis. Oecologia 105:361-368

Duffy JE, Hay ME (1994) Herbivore resistance to seaweed chemical defense: the roles of herbivore mobility and predation risk. Ecology 75:1304-1319

Duffy JE, Hay ME (2000) Strong impacts of grazing amphipods on the organization of a benthic community. Ecol Monogr 70:237-263

Faulkner JD (1998) Marine natural products. Nat Prod Rep 15: 113-158

Giamoustaris A, Mithen R (1995) The effect of modifying the glucosinolate content of leaves of oilseed rape on its interaction with specialist and generalist pests. Ann Appl Biol 126:347-363

Glantz SA (1992) Primer of biostatistics. McGraw-Hill, Inc, New York

Hatcher BG, Larkum AWD (1983) An experimental analysis of factors controlling the standing crop of epilithic algal community on a coral reef. J Exp Mar Biol Ecol 69:61-84

Hay ME (1984) Predictable spatial escapes from herbivory: how do these affect the evolution of herbivore resistance in tropical marine communities? Oecologia 64:396-407

Hay ME (1985) Spatial patterns of herbivore impact and their importance in maintaining algal species richness. Proc 5th Int Coral Reef Congr 4:29-34

Hay ME (1986) Associational plant defenses and the maintenance of species diversity: turning competitors into accomplices. Am Nat 128:617-641

Hay ME (1991) Fish-seaweed interactions on coral reefs: effects of herbivorous fishes and adaptations of their prey. In: Sale PF (ed) The ecology of fishes on coral reefs. Academic Press, San Diego, p 96-119 
Hay ME (1996) Marine chemical ecology: what's known and what's next? J Exp Mar Biol Ecol 200:103-134

Hay ME (1997) Calcified seaweeds on coral reefs: complex defenses, trophic relationships, and value as habitats. Proc 8th Int Coral Reef Symp 1:713-718

Hay ME, Fenical W (1988) Marine plant-herbivore interactions: the ecology of chemical defense. Annu Rev Ecol Syst 19:111-145

Hay ME, Fenical W (1996) Chemical ecology and marine biodiversity: insights and products from the sea. Oceanography 9:10-20

Hay ME, Sutherland JP (1988) The ecology of rubble structures of the South Atlantic Bight: a community profile. US Fish Wildl Serv Biol Rep 85

Hay ME, Fenical W, Gustafson K (1987) Chemical defense against diverse coral reef herbivores. Ecology 68: 1581-1591

Hay ME, Duffy JE, Fenical W (1988a) Seaweed chemical defenses: among-compound and among-herbivore variance. Proc 6th Int Coral Reef Congr 3:43-48

Hay ME, Paul VJ, Lewis SM, Gustafson K, Tucker J, Trindell R (1988b) Can tropical seaweeds reduce herbivory by growing at night? Diel patterns of growth, nitrogen content, herbivory, and chemical versus morphological defenses. Oecologia 75:233-245

Hay, ME, Kappel QE, Fenical W (1994) Synergisms in plant defenses against herbivores: interactions of chemistry, calcification, and plant quality. Ecology 75:1714-1726

Hay ME, Stachowicz JJ, Cruz-Rivera E, Bullard S, Deal MS, Lindquist N (1998) Bioassays with marine and freshwater macroorganisms. In: Haynes KF, Millar JG (eds) Methods in chemical ecology, Vol 2, Bioassay methods. Chapman and Hall, New York, p 39-141

Hughes TP (1994) Catastrophes, phase shifts, and large-scale degradation of a Caribbean coral reef. Science 265: $1547-1550$

Karban R, Baldwin LT (1997) Induced responses to herbivory. Chicago University Press, Chicago

Lawrence JM (1975) On the relationships between marine plants and sea urchins (Echinodermata: Echinoidea). Oceanogr Mar Biol Annu Rev 13:213-286

Lewis SM (1985) Herbivory on coral reefs: algal susceptibility

Editorial responsibility: Joseph Pawlik (Contributing Editor), Wilmington, North Carolina, USA to herbivorous fishes. Oecologia 65:370-375

Lewis SM (1986) The role of herbivorous fishes in the organization of a Caribbean reef community. Ecol Monogr 56: $183-200$

Lubchenco J, Gaines SD (1981) A unified approach to marine plant-herbivore interactions. I. Populations and communities. Annu Rev Ecol Syst 12:405-437

McConnell OJ, Hughes PA, Targett NM, Daly J (1982) Effects of secondary metabolites on feeding by the sea urchin Lytechinus variegatus. J Chem Ecol 8:1427-1453

Miller MW, Hay ME (1996) Coral-seaweed-nutrient-grazer interactions on temperate reefs. Ecol Monogr 66:323-344

Paul VJ (ed) (1992) Ecological roles of marine natural products. Comstock, New York

Paul VJ, Fenical W (1986) Chemical defense in tropical green algae, order Caulerpales. Mar Ecol Prog Ser 34:157-169

Paul VJ, Van Alstyne K (1988) Chemical defense and chemical variation in the genus Halimeda. Coral Reefs 6:263-269

Paul VJ, Van Alstyne K (1992) Activation of chemical defense in the tropical green algae Halimeda spp. J Exp Mar Biol Ecol 160:191-203

Peterman RM (1990) Statistical power analysis can improve fisheries research and management. Can J Fish Aquat Sci 47:2-15

Ragan MA, Glombitza KW (1986) Phlorotannins, brown algal polyphenols. Prog Phycol Res 4:129-241

Stachowicz JJ, Hay ME (1999) Reducing predation through chemically-mediated camouflage: indirect effects of plant defenses on herbivores. Ecology 80:495-509

Steinberg D, Estes JA, Winter FC (1995) Evolutionary consequences of food chain length in kelp forest communities. Proc Natl Acad Sci USA 92:8145-8148

Van Etten CH, Tookey HL (1979) Chemistry and biological effects of glucosinolates. In: Rosenthal GA, Janzen DH (eds) Herbivores: their interaction with secondary plant metabolites. Academic Press, New York, p 471-500

Young DN, Howard BM, Fenical W (1980) Subcellular localization of brominated secondary metabolites in the red alga Laurencia snyderae. J Phycol 16:182-185

Wolfe G, Steinke M, Kirst G (1997) Grazing activated chemical defense in a unicellular marine alga. Nature 387: 894-897

Submitted: April 25, 2000; Accepted: August 15, 2000

Proofs received from author(s): October 16, 2000 